ISSN 0258-7122

Bangladesh J. Agril. Res. 33(3) : 363-373, September 2008

\title{
TECHNICAL EFFICIENCY OF WHEAT GROWERS IN SOME SELECTED SITES OF DINAJPUR DISTRICT OF BANGLADESH
}

\author{
M. KAMRUZZAMAN ${ }^{1}$ AND MOHAMMAD HEDAYETUL ISLAM ${ }^{2}$
}

\begin{abstract}
The present study was undertaken to find out the technical efficiency and factors affecting inefficiency of wheat production in Dinajpur District of Bangladesh. The data were collected from 01 July to 30 September 2004. The range of technical efficiency varies from $40 \%$ to $99 \%$ and the average was $70.33 \%$. Farmers with optimum sowing and optimum harvest were technically more efficient than the farmers with late sowing. In all farms technical efficiency was much higher for the farmers who use sandy loam soil for wheat production than the farmers who did not use sandy loam soil. There was a positive relationship between the educational level and technical efficiency of wheat practicing farmers. The farmers who contacted frequently with extension workers were technically more efficient than who contacted less with extension workers. Therefore, maintaining of optimum sowing and harvesting time, use of sandy loam soil, high level of farming experience and education are important factors for obtaining maximum achievable yield.
\end{abstract}

Kew Words: Technical efficiency, wheat growers, optimum sowing and harvest.

\section{Introduction}

With the rapid increase in population and urbanization, the demand for wheat production has been increasing. To meet up growing demand without importing wheat area under wheat should be increased. In many regions of Bangladesh, wheat is an attractive crop. Rice is rarely grown in lighter soils located in more elevated areas and it is not suitable to grown where reliable irrigation services are absent. These latter conditions are present in the northwestern, north central, south central and south western regions of the country, precisely where most wheat production, presently is concentrated. Though these areas are suitable for wheat production, but still only $27 \%$ of the potential areas are under wheat cultivation. On the other hand, on-farm trial of wheat at BARI found wheat yield of $3.23 \mathrm{t} / \mathrm{ha}$ as against the national average of $1.74 \mathrm{t} / \mathrm{ha}$ in 2004-2005 (BBS, 2005). Area, production and yield of wheat is given in Table 1.

Therefore, there is a potential of increasing wheat production from existing cultivating areas using available resources if the farmers can operate at the

\footnotetext{
${ }^{1}$ Assistant Professor, Department of Agricultural Economics, BSMRAU, Gazipur-1706, ${ }^{2}$ Former MS student, Department of Agricultural Economics, BSMRAU, Gazipur-1706, Bangladesh.
} 
maximum obtainable yield level. Maximum obtainable yield level can be determined through estimation of frontier production function. Some farmers may produce maximum obtainable wheat yield and some farmers may not produce maximum obtainable yield level due to some inefficiency factors. Therefore, with the importance of wheat cultivation in Bangladesh, it is necessary to find out the maximum level of wheat produced per unit of land using the existing level of resources and factors affecting inefficiency of not obtaining the maximum yield level. Therefore, the specific objective of the present study is:

(i) to estimate the level of technical efficiency of wheat production and factors affecting inefficiency using the stochastic frontier production function.

Table 1. Area, production and yield of wheat during the period of 1999-2005.

\begin{tabular}{lllll}
\hline Year & Area (ha) & Production (MT) & Yield (MT/ha) \\
\hline $1999-00$ & 832 & 1840 & 2.20 \\
$2000-01$ & 772 & 1673 & 2.16 \\
$2001-02$ & 742 & 1606 & 2.16 \\
$2002-03$ & 706 & & 2.13 \\
$2003-04$ & 642 & & 1.95 \\
$2004-05$ & 558 & 976 & 1.74 \\
\hline
\end{tabular}

\section{Materials and Method}

\section{Selection of the study area and sample}

Dinajpur District was selected purposively as a study area because this district is one of the leading wheat producing areas of Bangladesh. Nawabganj thana was selected randomly from the 13 thanas of Dinajpur District as the study area. A preliminary survey was conducted in some villages of Nawabganj thana under Dinajpur District to gather primary knowledge about the wheat production, and efficiency of the wheat growers. After preliminary visit, five villages, namely Krishnajibonpur, Monirumpur, Showgunkhula, Pravanandapur, Muradpur were selected randomly as the study area. Data for the study were collected from 01 July to 30 September 2004. A total of 60 farmers were selected for the study using random sampling technique. Among the randomly selected 60 farmers, 30 were small, 15 were medium, and 15 were large.

\section{Stochastic production frontier and technical inefficiency model}

The modeling and estimation of stochastic frontier production functions, originally proposed by Aigner et al. (1977) and Meeusen and Van Den Broeck (1977), has been an important area of economic study in the last two decades. Reviews of applications in agriculture are given by Battese (1992), Bravo-Ureta and Pinheiro 
(1993) and Coelli (1996). In the latter half of the last decade, various models have been proposed for the inefficiency effects in stochastic frontier production functions. Kumbhakar et al. (1991) specified stochastic production frontier of Zellner-Revankar type, in which the technical inefficiency effects were assumed to be a function of the values of other observable explanatory variables. In addition, their model considered allocative and scale efficiencies. Huang and Liu (1994) specified a non-neutral stochastic frontier production function, in which the technical inefficiency effects were specified in terms of various firm-specific variables and interactions among these variables and the input variables in the frontier. Battese and Coelli (1995) proposed a stochastic frontier production function for panel data, in which the technical inefficiency effects were specified in terms of various explanatory variables, possibly including time. Coelli (1994) expanded the FRONTIER program to estimate the stochastic frontier model of Battese and Coelli (1992). This analysis had been done to observe the contribution of the effect of factors influencing technical efficiency and inefficiency on wheat production in the selected areas of Bangladesh. Following Aigner et al. (1977) and Meeusen and Van Den Broeck (1977), the stochastic frontier production function with two error terms can be modeled as:

$$
\mathrm{Y}=\mathrm{f}\left(\mathrm{X}_{\mathrm{i}}, \beta\right) \exp \left(\mathrm{V}_{\mathrm{i}}-\mathrm{U}_{\mathrm{i}}\right)
$$

Where $Y_{i}$ is the production of the $i$-th farm $(i=1,2,3 \ldots \ldots \ldots \ldots \ldots . . . n), X_{i}$ is a $(1 \times k)$ vector of functions of input quantities applied by the $\mathrm{i}$-th farm, 1 is a $(\mathrm{k} \times 1)$ vector of unknown parameters to be estimated, $\mathrm{V}_{\mathrm{i}} \mathrm{s}$ are random variables assumed to be independently and identically distributed $N\left(0, \sigma^{2} u\right)$ and independent of $U_{i} \mathrm{~s}$. Following Battese and Coelli (1995), the technical inefficiency effects, $U_{i}$ in equation (1) can be expressed as:

$$
\mathrm{U}_{\mathrm{i}}=\mathrm{Z}_{\mathrm{i}} \delta+\mathrm{W}_{\mathrm{i}}
$$

Where, $\mathrm{W}_{\mathrm{i}} \mathrm{s}$ are random variables, defined by the truncation of the normal distribution with zero mean and variance $\sigma^{2} \mathrm{u}$, such that the point of truncation is $Z_{i} \delta$, i.e., $W_{i} \geq-Z_{i} \delta$. Besides the farm-specific variables, the 4 variables in equation is (2) may also include input variables in the stochastic production frontier (I), provided that the inefficiency effects are stochastic. If $\mathrm{Z}$ - variables also include interactions between farm-specific and input variables, then a Huang and Liu (1994) non-neutral stochastic frontier is obtained.

The technical efficiency of the ith sample farm, denoted by $\mathrm{TE}_{\mathrm{i}}$ is given by:

$$
\mathrm{TE}_{\mathrm{i}}=\exp \left(-\mathrm{U}_{\mathrm{i}}\right)=\mathrm{Y}_{\mathrm{i}} / \mathrm{f}\left(\mathrm{X}_{\mathrm{i}}, \beta\right) \exp \left(\mathrm{V}_{\mathrm{i}}\right)-\mathrm{Y}_{\mathrm{i}} / \mathrm{Y}_{\mathrm{i}}
$$


Where $Y_{i}=f\left(X_{i}, \beta\right) \exp \left(V_{i}\right)$ is the farm-specific stochastic frontier. If $Y_{i}$ is equal to $Y_{i}$ then $T E_{i}=1$, reflects $100 \%$ efficiency. The difference between $Y_{i}$ and $Y_{i}$ is embedded in $\mathrm{U}_{\mathrm{i}}$ (Dey et al., 1999). If $\mathrm{U}_{\mathrm{i}}=0$, implying that production lies on the stochastic frontier, the farm obtains its maximum attainable output given its level of input. If $\mathrm{U}_{\mathrm{i}}<0$, production lies below the frontier and indication inefficiency.

\section{Empirical model}

Two types of function, namely Cobb-Douglas and translog dominate the technical efficiency literature. In this study, It is assumed that the Cobb-Douglas is the appropriate form of the frontier production function. The stochastic production function which is used for the wheat producers was specified as:

$$
\begin{aligned}
\ln Y i= & \beta_{0} \beta_{1} \ln \left(X_{1}\right)+\beta_{2} \ln \left(X_{2}\right)+\beta_{3} \ln \left(X_{3}\right)+\beta_{4} \ln \left(X_{4}\right)+\beta_{5} \ln \left(X_{5}\right)+\beta_{6} \ln \left(X_{6}\right)+ \\
& \beta_{7} \ln \left(X_{7}\right)+\beta_{8} \ln \left(X_{8}\right)+\beta_{9} \ln \left(X_{9}\right)+\beta_{10} \ln \left(X_{10}\right)+\beta_{11} \ln \left(X_{11}\right)+\beta_{12} \ln \left(X_{12}\right)+ \\
& \beta_{13} \ln \left(X_{13}\right)
\end{aligned}
$$

Where, $I n=$ Natural logarithm, $Y=$ Gross return (Tk./ha), $X_{1}=$ Hired labor cost (Tk./ha), $X_{2}=$ Family labor cost (Tk./ha), $X_{3}=$ Cost of urea (Tk./ha), $X_{4}=$ Cost of TSP (Tk./ha), $\mathrm{X}_{5}=$ Cost of MP (Tk./ha), $\mathrm{X}_{6}=$ Irrigation cost (Tk./ha), $\mathrm{X}_{7}=$ Animal power cost (Tk./ha), $\mathrm{X}_{8}=$ Mechanical power cost (Tk./ha), $\mathrm{X}_{9}=$ Seed cost (Tk./ha), $\mathrm{X}_{10}=$ Interest on operating capital (Tk./ha), $\mathrm{X}_{11}=$ Land rent (Tk./ha), $\mathrm{X}_{12}=$ Small farmer dummy (I if small farmer, 0 otherwise), $\mathrm{X}_{13}=$ Medium farmer dummy (I if medium farmer, 0 otherwise).

The technical inefficiency effects $U_{i}$ are defined as:

$\mathrm{U}_{\mathrm{i}}=\delta_{0}+\delta_{\mathrm{j}} \mathrm{Z}_{\mathrm{j}}+\mathrm{W}_{\mathrm{i}}$

Where, $Z_{\mathrm{i}}=$ Date of sowing dummy (I if optimum sowing and 0 otherwise), $Z_{2}=$ Date of harvesting dummy ( 1 if optimum harvesting and 0 otherwise), $Z_{3}=$ Education of the respondent (Measured in year of schooling), $Z_{4}=$ Farming experience (measured in year of farming), $Z_{5}=$ Soil type (I if sandy loam soil and 0 otherwise), $Z_{6}=$ Frequency of extension contact

\section{Results and Discussion}

\section{Estimates of stochastic frontier production function}

The estimates of stochastic frontier production function along with other variables are presented in Table 2. In case of wheat farming, the result of frontier production function showed that different cost items like hired labour, family labour, urea, TSP, MP, mechanical power, seed, interest on operating capital, land use were significant. Among them, family labour cost, fertilizer cost, 
mechanical power cost, seed cost, interest on operating capital, land use cost, small farm dummy and medium farm dummy were significant at $1 \%$ level. It means that the mentioned cost items influence significantly on production of wheat.

Table 2. Maximum likelihood estimates of the stochastic frontier production and factors influencing inefficiency of wheat production in the study area.

\begin{tabular}{lllll}
\hline \multicolumn{1}{c}{ Variables } & \multicolumn{1}{c}{ Parameter } & Co-efficient & \multicolumn{1}{c}{ t-ratio } \\
\hline Constant & $\beta_{0}$ & $22.67^{*}$ & 16.21 \\
In Hired labour cost & $\beta_{1}$ & $-0.10^{* *}$ & -2.09 \\
In Family labour cost & $\beta_{2}$ & $0.17^{*}$ & -5.49 \\
In Urea cost & $\beta_{3}$ & $0.29^{*}$ & 4.86 \\
In TSP cost & $\beta_{4}$ & $-0.13^{*}$ & -3.77 \\
In MP cost & $\beta_{5}$ & $0.17^{*}$ & 4.88 \\
in Irrigation cost & $\beta_{6}$ & $0.04 \mathrm{NS}$ & 1.19 \\
in Animal power cost & $\beta_{7}$ & $-0.01 \mathrm{NS}$ & -0.83 \\
In Mechanical power cost & $\beta_{8}$ & $-0.03^{*}$ & -6.35 \\
In Seed cost & $\beta_{9}$ & $-0.40^{*}$ & -5.33 \\
in Interest on operating capital & $\beta_{10}$ & $0.36^{*}$ & 4.53 \\
In Land rent & $\beta_{11}$ & $0.41^{*}$ & -8.48 \\
Small farmer dummy & $\beta_{12}$ & $0.27^{*}$ & 9.45 \\
Medium farmer dummy & $\beta_{13}$ & $0.24^{*}$ & 9.45 \\
$\sigma^{2}$ & & $0.0039^{*}$ & 5.38 \\
Constant & $\delta_{0}$ & $1.09^{*}$ & 19.40 \\
Date of sowing dummy & $\delta_{1}$ & $0.05 \mathrm{NS}$ & 0.80 \\
Date of harvesting dummy & $\delta_{2}$ & $-0.01 \mathrm{NS}$ & -0.16 \\
Education in years & $\delta_{3}$ & $-0.05^{* * *}$ & -1.42 \\
Farming experience in years & $\delta_{4}$ & $-0.18^{*}$ & -6.63 \\
Soil type dummy & $\delta_{5}$ & $-0.05^{*}$ & -2.45 \\
Frequency of extension contact & $\delta_{6}$ & $-0.06^{*}$ & -2.63 \\
\hline Log likelihood function & \multicolumn{3}{c}{10.11} \\
Log likelihood ratio test( 2) & \multicolumn{3}{c}{$20.33^{*}$} \\
\hline
\end{tabular}

Source: Field survey (2004)

Note: and $*$ indicates significant at $1 \%, 5 \%$ and $10 \%$ level respectively and NS indicate not significant.

\section{Inefficiency factors of wheat production}

In order to quantify determinants of efficiency or inefficiency of wheat production, some socio-economic variables were included in the stochastic frontier production, function. The estimated co-efficients in the explanatory variables in the model have important implication. The negative and significant 
co-efficient of education implies that the farmers with more education tend to be less inefficient. So, education can reduce the inefficiency of wheat production or it can increase the efficiency of wheat production.

The negative co-efficient of farming experience measured in years indicated that the farmers with more experience tend to be less inefficient. So, farming experience can increase the technical efficiency of wheat production (Table 2). The negative co-efficient of soil type dummy indicated that the farmers who cultivated in sandy loam soil are more efficient than the farmers with cultivation in other soil type. The negative and significant co-efficient of frequency of extension contacted implies that the farmers who make frequent contact with extension personnel were technically more efficient than the farmers who did not contact frequently with the extension personnel. On the other hand, optimum date of sowing and harvesting dummy were insignificant for the wheat producers in the study area.

\section{Range of technical efficiency (TE) according to farm size}

Different range of technical efficiency of different categories of farmers is depicted in Fig. 1.1. The figures showed that the different ranges of technical efficiency of small, medium, and large farmers clearly differ in terms of skewness. Most of the farmers of different categories of farm sizes lie between the technical efficiency ranges of $71-85 \%$, followed by the range of $40-55 \%$. The figure showed that about $47 \%$ farmers of small farm category, $40 \%$ of the medium farm category, and $33.3 \%$ of the large farm category lie within the range of $71-85 \%$ technical efficiency. It is also evident that the higher the farm size, the lower the TE. The other range of TE showed that $27 \%$ of the small farm category, $20 \%$ of the medium farm category. $33.3 \%$ of the large farm category lie within the range of $40-55 \%$ of technical efficiency.

\section{Showing date and technical efficiency}

Table 3 showed that in the case of optimum sowing, small farmer's efficiency level was comparatively high $(72.62 \%)$ than late sowing $(47.75 \%)$. Similar picture was found in the case of medium and large farms. If we consider all farm categories then we also find that farmers with optimum sowing were technically more efficient than the farmers with late sowing. Therefore, optimum sowing had positive hmpact on achieving higher technical efficiency in wheat production. 


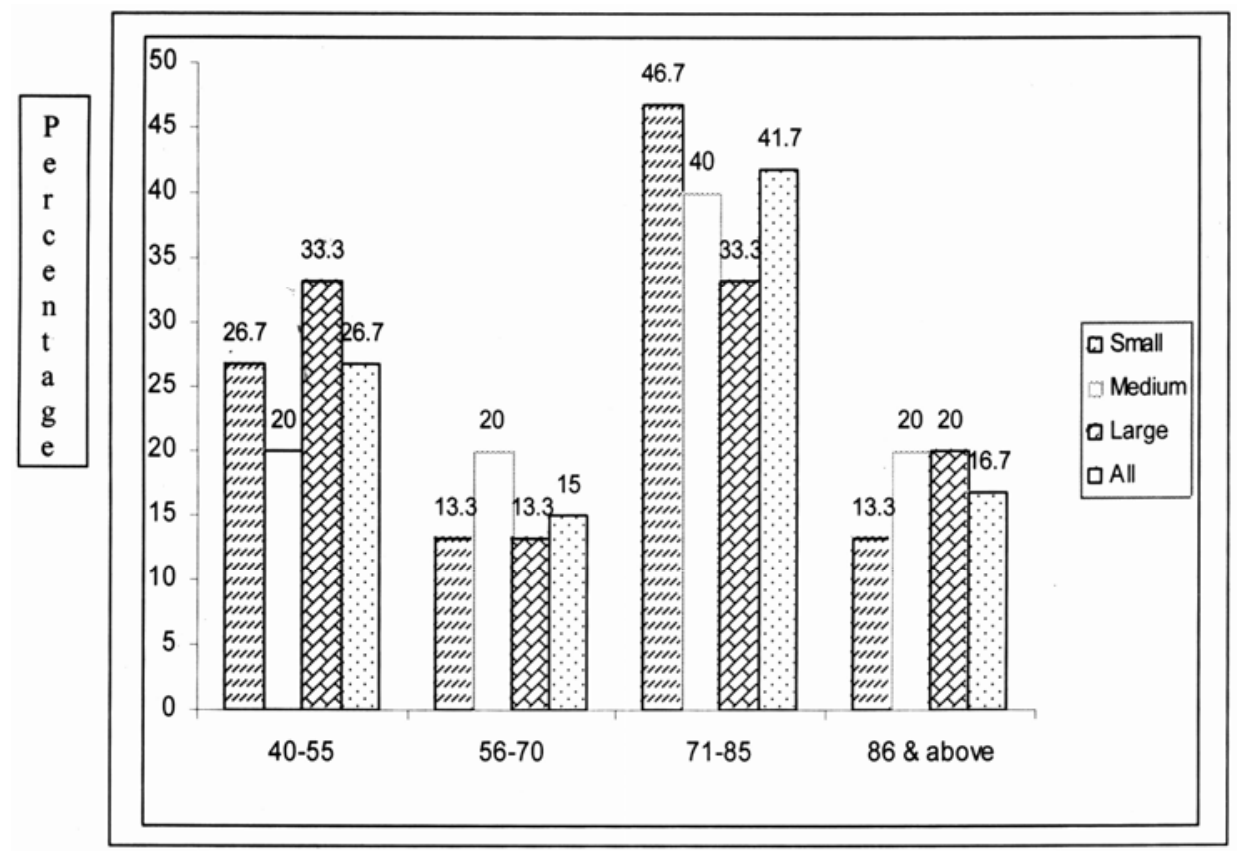

Fig 1. Percent of farmers lies in different ranges of technical efficiency according to farm category.

Table 3. Relationship between date of sowing and technical efficiency of wheat producers.

\begin{tabular}{l|c|c|c|c|c|c|c|c}
\hline \multirow{3}{*}{ Sowing time } & \multicolumn{5}{c|}{ Farm category } & \multicolumn{2}{c}{ All farm } \\
\cline { 2 - 7 } & \multicolumn{2}{|c|}{ Small } & \multicolumn{2}{c}{ Medium } & \multicolumn{2}{c}{ Large } & \multirow{2}{*}{ Mean } & \multirow{2}{*}{ SD } \\
\cline { 2 - 8 } & Mean & SD & Mean & SD & Mean & SD & & \\
\hline Late sowing & 47.75 & 2.10 & 45.00 & - & - & - & 47.20 & 1.71 \\
Optimum sowing & 72.62 & 2.91 & 75.21 & 4.09 & 69.53 & 4.95 & 72.44 & 2.17 \\
All & 69.30 & 2.98 & 73.20 & 4.31 & 69.53 & 4.95 & 70.33 & 2.19 \\
\hline
\end{tabular}

Source: Field survey (2004). Note: Late sowing = 01 December and onward, Optimum. Sowing $=15$ to 30 November. SD - Standard deviation

\section{Harvesting date and technical efficiency}

Table 4 Indicated that in the case of optimum harvest, small farmers' efficiency level was comparatively high (72\%) than late harvest $(52.33 \%)$. Similar picture was found in the case of medium and large farms. If we consider all farms then we find that farmers with optimum harvest were technically more efficient than the farmers with late harvest. Hence, optimum harvest time had positive impact on increasing technical efficiency of wheat producers. 
Table 4. Relationship between harvesting date and technical efficiency of wheat producers.

\begin{tabular}{l|l|c|c|c|c|c|c|c}
\hline \multirow{2}{*}{ Harvesting time } & \multicolumn{7}{c|}{ Farm category } & \multicolumn{2}{c}{ All farm } \\
\cline { 2 - 8 } & \multicolumn{2}{|c|}{ Small } & \multicolumn{2}{c|}{ Medium } & \multicolumn{2}{c}{ Large } & \multirow{2}{*}{ Mean } & \multirow{2}{*}{ SD } \\
\cline { 2 - 9 } & Mean & SD & Mean & SD & Mean & SD & & \\
\hline Late harvest & 52.33 & 4.84 & 57.00 & 12.00 & - & - & 54.20 & 5.49 \\
Optimum harvest & 71.19 & 4.08 & 75.69 & 4.39 & 69.53 & 4.95 & 71.80 & 3.25 \\
All & 69.30 & 3.93 & 73.20 & 4.31 & 69.53. & 4.95 & 70.33 & 3.19 \\
\hline
\end{tabular}

Source: Field survey (2004). Note: Late harvest $=20$ March and onwara, Optimum harvest:

10 to 19 March. SD Standard deviation

\section{Soil type and technical efficiency}

The technical efficiency of wheat producers in the case of sandy loam soil was comparatively high $(77.33 \%)$ than the other soil types for small farmers (Table 5). Similar trend was also found in the case of medium and large farmers. In all farms, technical efficiency was much higher $(78.33 \%)$ for the farmers who uses sandy loam soil for wheat production than the farmers who did not uses sandy loam soil. Therefore, soil type highly influenced technical efficiency of wheat production in the study area.

Table 5. Relationship between soil type and technical efficiency of wheat producer.

\begin{tabular}{l|c|c|c|c|c|c|c|c}
\hline \multirow{2}{*}{ Soil type } & \multicolumn{5}{c|}{ Farm category } & \multicolumn{2}{c}{ All farm } \\
\cline { 2 - 8 } & \multicolumn{2}{|c|}{ Small } & \multicolumn{2}{c}{ Medium } & \multicolumn{2}{c}{ Large } & \multirow{2}{*}{ Mean } & SD \\
\cline { 2 - 8 } & Mean & SD & Mean & SD & Mean & SD & & \\
\hline Other soil & 50.56 & 2.68 & 49.67 & 3.33 & 49.60 & 3.75 & 50.12 & 2.27 \\
Sandy loam & 77.33 & 3.65 & 79.08 & 4.65 & 79.50 & 5.52 & 78.33 & 2.94 \\
All & 69.30 & 3.98 & 73.20 & 5.35 & 69.53 & 5.65 & 70.33 & 3.19 \\
\hline
\end{tabular}

Source: Field survey (2004). SD Standard deviation

\section{Education and technical efficiency}

There was a positive relationship between the educational level and technical efficiency of wheat farmers. This implied that the farmers with more education respond more readily in using the improved technology and produce more output with similar amount of inputs. In the case of small farmers, higher secondary educated farmers were technically more efficient $(98.75 \%)$ than the other categories of farmers. Similar image was found in the case of medium and large farms. The highest technical efficiency was achieved by the higher educated farmers and the lowest by the illiterate farmers (Table 6). 
Table 6. Relationship between education status and technical according to farm category in the study area.

\begin{tabular}{|c|c|c|c|c|c|c|c|c|}
\hline \multirow{3}{*}{$\begin{array}{l}\text { Educational } \\
\text { status }\end{array}$} & \multicolumn{6}{|c|}{ Farm category } & \multicolumn{2}{|c|}{ All farm } \\
\hline & \multicolumn{2}{|c|}{ Small } & \multicolumn{2}{|c|}{ Medium } & \multicolumn{2}{|c|}{ Large } & \multirow{2}{*}{ Mean } & \multirow{2}{*}{ SD } \\
\hline & Mean & SD & Mean & SD & Mean & SD & & \\
\hline Illiterate & 45.00 & 0.71 & 45.00 & - & 43.00 & 0.00 & 44.43 & 153 \\
\hline Upto secondary & 56.63 & 1.13 & 55.33 & 3.33 & 56.40 & 1.69 & 56.31 & 2.91 \\
\hline $\begin{array}{l}\text { Secondary to } \\
\text { higher secondary }\end{array}$ & 75.07 & 0.52 & 73.75 & 1.21 & 75.60 & 0.98 & 74.78 & 1.91 \\
\hline $\begin{array}{l}\text { More than higher } \\
\text { secondary }\end{array}$ & 98.75 & 0.25 & 99.00 & 0.00 & 99.00 & 0.00 & 98.90 & 0.60 \\
\hline All & 69.30 & 2.68 & 73.20 & 4.11 & 69.53 & 5.95 & 70.33 & 2.59 \\
\hline
\end{tabular}

Source: Field survey (2004). SD = Standard deviation

\section{Farming experience and technical efficiency}

The farmers with more farming experience were technically more efficient than the farmers with less experience (Table 7). In all farm category, farmers with experience ranged From 30 to 39 years were technically more efficient $(88.22 \%)$ than farmers with experience ranged from 20 to 29 years $(71.33 \%)$ and 5 to 19 years $(51.80 \%)$. This trend was similar for small, medium, and large farm category.

Table 7. Relationship between farming experience and technical efficiency of wheat producers according to farm category in the study area.

\begin{tabular}{|c|c|c|c|c|c|c|c|c|}
\hline \multirow{3}{*}{$\begin{array}{l}\text { Farming } \\
\text { experience } \\
\text { (years) }\end{array}$} & \multicolumn{6}{|c|}{ Farm category } & \multicolumn{2}{|c|}{ All farm } \\
\hline & \multicolumn{2}{|c|}{ Small } & \multicolumn{2}{|c|}{ Medium } & \multicolumn{2}{|c|}{ Large } & \multirow{2}{*}{ Mean } & \multirow{2}{*}{ SD } \\
\hline & Mean & SD & Mean & SD & Mean & SD & & \\
\hline 5 to 19 & 51.20 & 1.69 & 54.50 & 4.51 & 51.00 & 3.65 & 51.80 & 1.69 \\
\hline 20 to 29 & 71.55 & 1.56 & 71.17 & 1.61 & 71.00 & 3.60 & 71.33 & 14.53 \\
\hline 30 to 39 & 85.25 & 4.07 & 90.60 & 4.64 & 90.60 & 5.54 & 88.22 & 2.65 \\
\hline 40 and above & 98.00 & - & - & - & - & - & 98.00 & - \\
\hline All & 69.30 & 2.68 & 73.20 & 4.11 & 69.53 & 5.95 & 70.33 & 2.59 \\
\hline
\end{tabular}

Source: Field survey (2004). SD = Standard deviation

\section{Frequency of extension contact and technical efficiency}

Table 8 indicated that the farmers who contacted frequently with extension workers were technically more efficient than the farmers with less contacted with extension workers. In all farm category, the highest technical efficiency (99\%) was achieved by those farmers who contacted 4 to 3 times with extension workers during the production period. Less technical efficiency $(51.07 \%)$ was achieved by the farmers who did not contact with extension workers during the production period. The similar trend was found in different farm category farmers. 
Table 8. Technical efficiency and frequency of contact with extension workers according to farm category for the wheat producers.

\begin{tabular}{l|c|c|c|c|c|c|c|c}
\hline \multirow{2}{*}{$\begin{array}{c}\text { Frequency of } \\
\text { contact }\end{array}$} & \multicolumn{9}{|c|}{ Farm category } & \multicolumn{3}{c}{ All farm } \\
\cline { 2 - 8 } & \multicolumn{2}{|c|}{ Small } & \multicolumn{2}{c|}{ Medium } & \multicolumn{2}{c}{ Large } & \multirow{2}{*}{ Mean } & \multirow{2}{*}{ SD } \\
\cline { 2 - 8 } & Mean & SD & Mean & SD & Mean & SD & & \\
\hline No contact & 51.29 & 3.61 & 54.50 & 4.11 & 46.00 & 2.78 & 51.07 & 2.12 \\
1 to 3 & 71.15 & 2.36 & 72.88 & 1.65 & 67.56 & 3.25 & 70.65 & 1.454 \\
4 to 5 & 99.00 & 0.00 & 99.00 & 0.00 & 99.00 & 00 & 99.00 & 0.00 \\
\hline All & 69.30 & 2.68 & 73.20 & 4.11 & 69.53 & 4.65 & 70.33 & 2.09 \\
\hline
\end{tabular}

Source: Field survey (2004). SD = Standard deviation

\section{Conclusion and Recommendation}

In order to quantify determinants of inefficiency of wheat production some socioeconomic variables were included in the stochastic frontier production function. The inefficiency model implies that farmers with optimum sowing and harvest were technically more efficient than the farmers with late sowing and harvest. Therefore, optimum sowing and harvest date had positive impact on increasing technical efficiency of wheat producers. There was a positive relationship between the educational level and technical efficiency of wheat producers. In all farm category, farmers with experience range of 30 to 39 years were technically more efficient $(88.22 \%)$ followed by farmers with experience range of 20 to 29 years $(71.33 \%)$ and 5 to 19 years $(51.80 \%)$. The farmers who contacted frequently with extension workers were technically more efficient than who contacted less with extension workers. Therefore, maintaining of optimum sowing and harvesting time, use of sandy loam soil, high level of farming experience and education are important factors for obtaining maximum achievable yield.

\section{References}

Ahrned, M., S. M. Elias, M.A. Uddin, and J.K. Shaha. 1988. Wheat Production in: An agro-ceonomic profile. Bangladesh Agricultural Research Institute.

Aigner, D., C.A.K. Lovell, and P. Schmidt. 1977. Formulation and estimation of stochastic frontier production functions models. Journal of Economics 6: 2 1-37.

Battese, G. E. 1992. Frontier production functions and technical efficiencies: A survey of applications in agricultural economics. Agricultural Economics 7: 185-208.

Battese, G.E. and G.S. Corra. 1977. Estimation of production frontier model: with Application to the Pastoral Zone of Eastern Australia. Australian Journal of Agricultural Economics 21: 169-179.

Battese, G.E., and T.J. Coelli. 1995. A model for technical inefficiency effects in a stochastic frontier production function for panel data. Empirical Economics 20: 325-332. 
Battese, G.E., and T.J. Coelli. 1992. Frontier production functions, technical efficiency and panel data: With application to paddy farmers in India. Journal of Productivity Analysis 3: 153-169.

BBS. 2005. Statistical Year Book of Bangladesh, Bureau of Statistics, Ministry of Planning, Government of the Peoples Republic of Bangladesh, Dhaka, Bangladesh.

Bravo-Ureta, B., and A.E. Pinheiro. 1993. Efficiency analysis of developing country agriculture. A review of the frontier function literature. Agricultural and Resource Econometrics Review 22: 88-101.

Coelli, T.J. 1994. A guide to FRONTIER version 4.1: A Computer Programme for Stochastic Frontier Production and Cost Function Estimation. Department of Econometrics, University of New England, Armidale, NSW 2351, Australia.

Coelli, T.J. and G.E. Battese. 1996. Identification of factors which influence the technical inefficiency of India farmers. Australian Journal of Agricultural Economics 40(2): 103- 128.

Dey, M. M., G. P. Gimbao, F. Z. Paraguas and P. B. Regaspi. 1999. Technical efficiency of Tilapia Grow-out Pond Operations in the Philippines. Aquaculture Economics and Management 3(3): 345-359.

Farrel, M.J. 1957. The measurement of productive efficiency. Journal of Royal Statistical Society; series a 120. Part 3: 253-28 1.

Huang, C.J. and Liu. 1994. A non-neutral stochastic frontier production function. journal of Productivity Analysis 5: 171 -180.

Kumbhakar, S.C., S. Ghosh and J.T. McGuckin. 1991. A general production frontier Approach for Estimating Determinants of Inefficiency in US Dairy Farms. Journal of Business and Economics Statistics 9: 276-286.

Meeusen, W., and J. van den Broeck. 1977. Efficiency estimation from Cobb-Douglas Production Function with Composed Error. International Economic Review 18: 435- 444. 